\title{
Introducing an Antisense Gene for a Cell-Wall-Bound Acid Invertase to Tomato (Lycopersicon esculentum) Plants Reduces Carbohydrate Content in Leaves and Fertility
}

\author{
Akio OHYAMA* and Masashi HIRAI \\ National Research Institute of Vegetables, Ornamental Plants and Tea (NIVOT), Ano, Mie, 514-2392, Japan \\ *Present address: Plant Breeding and Genetics Research Laboratory, Japan Tobacco Inc., 700 Higashibara, \\ Toyoda, Iwata, Shizuoka 438-0802, Japan
}

Received 21 October 1998; accepted 21 December 1998

\begin{abstract}
Partial Wiv-1 cDNA for a cell-wall-bound acid invertase isolated from wounded leaves of tomato (Lycopersicon esculentum) was introduced into tomato plants in an antisense orientation. The enzyme activity was markedly decreased in wounded leaves of 3 of 9 transformants. The soluble sugars and starch contents in the source leaves of these 3 transformants were reduced compared with control plants. These results suggest that the cell-wall-bound acid invertase encoded by Wiv-1 regulates the carbohydrate content in source leaves of tomato. Most of the transformants showed low fertility. It is possible that the enzyme encoded by $W_{i v}-1$ participates also in sink metabolism in tomato flowers.
\end{abstract}

\author{
Abbreviations \\ $\mathrm{PCR}$, polymerase chain reaction.
}

\section{Introduction}

Most plants contain multiple isozymes of invertase (EC 3.2.1.26). Cell-wall-bound acid invertases (extracellular or apoplastic) are localized in the apoplast and are ionically bound to cell walls (Hisajima and Arai 1978, Krishnan et al., 1985, Karuppiah et al., 1989). It has been proposed that these enzymes are involved in phloem unloading (Ruan and Patrick 1995, Ho 1996, Brown et al., 1997) and in sink strength (Weber et al., 1995, 1996, Cheng et al., 1996). In tomato plants, 4 distinct genes for the enzymes have been cloned and characterized (Godt and Roitsch 1997). However, the roles of each enzyme in sink and source tissues are still unclear.

We previously cloned Wiv-1 cDNA (Ohyama et al., 1998) from wounded leaves of tomato. Wiv-1 originates from the same gene as $\operatorname{Lin} 6$ cDNA (Godt and Roitsch 1997) and codes for a cell-wall-bound acid invertase. High levels of Wiv-1 (Lin6) mRNA are found in young flower buds (Godt and Roitsch 1997), stems, and wounded source leaves (Ohyama et al., 1998). To clarify the roles of the enzyme encoded by Wiv-1 in tomato plants, we introduced an antisense gene to tomato with respect to the heterologous promoter, and analyzed the transgenic tomato plants.

\section{Materials and Methods}

\subsection{Construction of $p B W I-2$}

A partial cDNA, Wiv-2, for a wound-inducible, cell -wall-bound acid invertase in tomato leaves was used for construction of a binary vector. The nucleotide sequence of the Wiv-2 cDNA extends from the 483rd nucleotide of the Wiv-1 (Ohyama et al., 1998) cDNA to $37 \mathrm{bp}$ downstream from the $3^{\prime}$ end of the Wiv-1 cDNA.

The gene for $\beta$-glucuronidase on plasmid pBI121 (Clontech Laboratories, Inc., Palo Alto, CA, USA) was excised by digestion with Sma I and Sac I. A 1. 4-kbp Wiv-2 cDNA, excised by Hinc II and Sac I from recombinant pBluescript $\mathrm{KS}+$ (Stratagene, La Jolla, CA, USA), was ligated to the resultant vector arm in the antisense orientation. The resultant plasmid, pBWI-2 (Fig. 1), was used for the transformation.

\subsection{Agrobacterium-mediated transformation}

Tomato cv. Syugyoku was transformed as described previously (Ohyama et al., 1995) by using Agrobacterium tumefaciens LBA4404 harboring pBWI -2. Regenerated plants were grown in a greenhouse and encouraged to self-set fruit by occasional vibration of the inflorescence. 


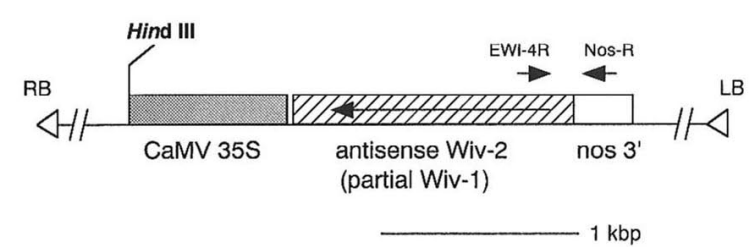

Fig. 1 Partial structure of plasmid pBWI-2. The cauliflower mosaic virus $35 \mathrm{~S}$ promoter (CaMV 35S) directs expression of an antisense gene (antisense Wiv-2) with the polyadenylation sequences of the gene for nopaline synthase (nos $3^{\prime}$ ). The other part of the plasmid is identical to the binary vector $\mathrm{pBI} 121$. LB and $\mathrm{RB}$ indicate left and right borders of $\mathrm{T}$ -DNA respectively. Primers EWI-4R and Nos-R used for detection of the transgene (Fig. 2) correspond to the sequences of positions indicated by arrows. The relevant restriction site (Hind III) for the Southern blotting analysis (Fig. 2) is shown.

\subsection{Screening of transformants by PCR}

Genomic DNA was isolated from young leaves of regenerated plants by the standard method (Murray and Thompson 1980). The reaction mixture $(20 \mu 1)$, which contained Ex Taq polymerase (Takara, Kyoto, Japan) and the primers EWI-4R (Fig. 1; 5'-AGTATCCATCTCTGCCCATCCAAG-3') and Nos-R (Fig. 1 ; 5'-ATCATCGCAAGACCGGCAAC-3'), was prepared according to the enzyme manufacturer's protocol. A thermal cycle consisting of $1 \mathrm{~min}$ at $94^{\circ} \mathrm{C}, 1 \mathrm{~min}$ at $55^{\circ} \mathrm{C}$, and $1 \mathrm{~min}$ at $72^{\circ} \mathrm{C}$, was repeated 25 times. PCR products were isolated on a $2 \%$ agarose gel and stained with ethidium bromide.

\subsection{Southern blotting analysis}

Genomic DNA was digested with Hind III, fractionated by $0.8 \%$ agarose gel electrophoresis, and then blotted onto a membrane. The blot was allowed to hybridize with ${ }^{32} \mathrm{P}-$ labeled Wiv-2 cDNA.

\subsection{Wounding of leaves and assay of enzymatic activity}

Source leaves were wounded and activities of acid invertase in cell-wall-bound fractions were assayed as described previously (Ohyama et al., 1995, 1998).

\subsection{RNA blotting analysis}

RNA blotting was analyzed as described previously (Ohyama et al., 1998) using ${ }^{32} \mathrm{P}$-labeled Wiv-2 cDNA as a probe.

\subsection{Determination of carbohydrate content}

Fully expanded source leaves were sampled at noon between July and September, 1997. Soluble sugars

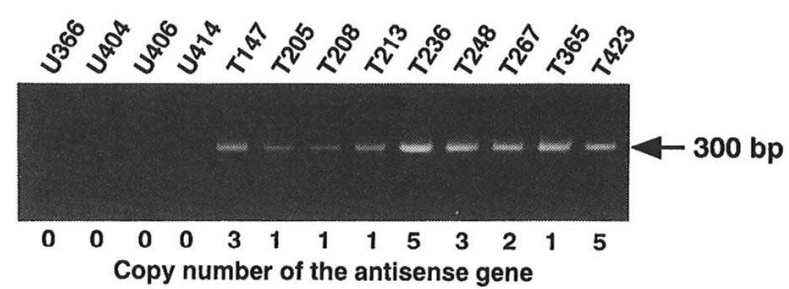

Fig. 2 DNA analysis of regenerated plants. $\mathrm{PCR}$ was done in a reaction mixture containing primers EWI-4R and Nos-R (Fig. 1) and genomic DNA from each regenerated plant as a template. Products of PCR were isolated on a $2 \%$ agarose gel and stained with ethidium bromide. The arrow shows a $300 \mathrm{bp}$ fragment amplified from the $3^{\prime}$ part of pBWI-2 (Fig. 1). The numbers below show the number of intact copies of the antisense gene estimated by Southern blotting analysis (see Materials and Methods).

were extracted with $80 \%$ ethanol and their concentrations were determined by high-performance liquid chromatography. Insoluble fractions in $80 \%$ ethanol were dissolved in a small amount of dimethyl sulfoxide, and then starch contents were determined enzymatically with an F-kit (Boehringer Mannheim, Tokyo, Japan).

\subsection{Pollen analysis}

Pollen grains were stained with acetocarmine. Stained grains were counted under a microscope.

\section{Results}

\subsection{DNA analysis of transformants containing an antisense Wiv-2}

Transformants were selected from 13 regenerated plants by PCR (Fig.2). A band of about $300 \mathrm{bp}$ derived from the antisense gene (Fig. 1) was detected in 9 plants (Fig. 2; T147, T205, T208, T213, T236, T248, T267, T365, T423). These transformants were further analyzed by Southern blotting. All transformants contained at least 1 intact copy of the antisense gene (Fig. 2). Four nontransformants (Fig. 2; U366, U404, U406, U414) were used as controls.

\subsection{Characteristics of the transformants}

Growth of all transformants but 1 was normal compared with the control plants (Fig. 3) ; T248 was stunted (data not shown). The percentage of stained pollen grains and the number of fruit were less in most transformants than those in the control plants (Table 1).

\subsection{Activity of cell-wall-bound acid invertase in wounded leaves of transformants}

Although the activity of cell-wall-bound acid inver- 
A

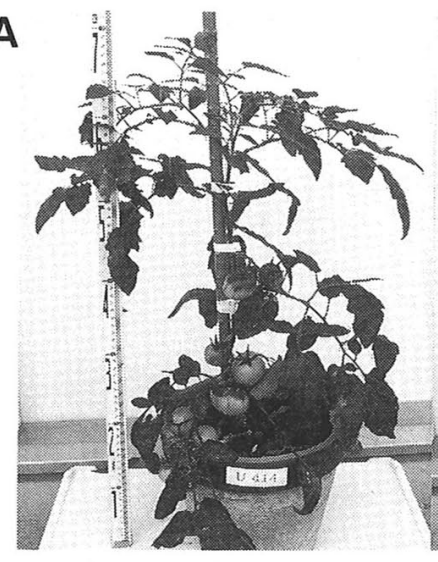

Fig. 3 Growth of tomato plants with an antisense Wiv-2 gene (pBWI-2). A: nontransformant (U414, control); B: transformant (T236).

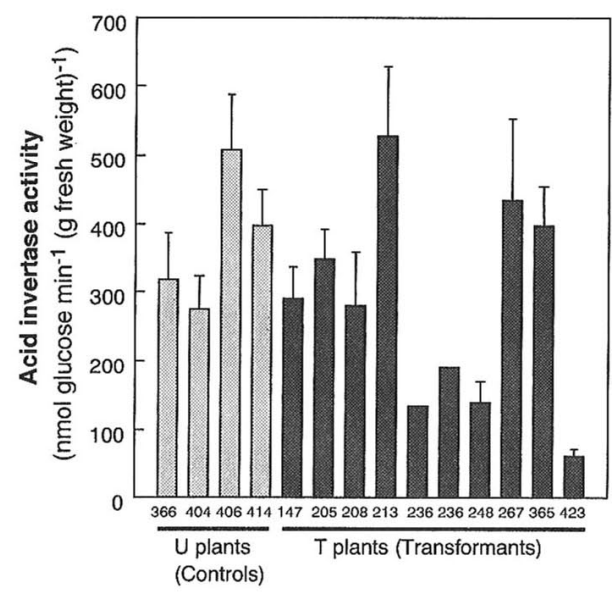

Fig. 4 Activity of cell-wall-bound acid invertase in wounded source leaves of transformants. Leaf discs cut from nontransformants (U plants) and transformants ( $\mathrm{T}$ plants) were incubated at $25^{\circ} \mathrm{C}$ in darkness for $96 \mathrm{~h}$. The activity in extracts of the leaf discs was then measured. Each column represents the mean of results of 3 experiments ( 2 for T236); vertical bars indicate standard error.

tase in intact leaves of tomato is very low, both the activity and Wiv- 1 mRNA levels are raised by wounding (Ohyama et al., 1998). Therefore we compared cell-wall-bound acid invertase activities in wounded leaves of transformants containing the antisense Wiv -2 (partial Wiv-1) gene. After $96 \mathrm{~h}$, levels of the activity varied (Fig. 4). Three transformants (T236, T248, T423) showed substantially less activity than control plants (Fig. 4). Activity in T423 was significantly lower $(P<0.05)$ than in a control plant, U404, which showed the lowest levels of activity among the controls (Fig. 4). These 3 transformants were selected and used for RNA and carbohydrate analyses.

\subsection{RNA blotting analysis of leaves of transfor- mants}

The levels of Wiv-1 (Ohyama et al., 1998) mRNA

\section{B}

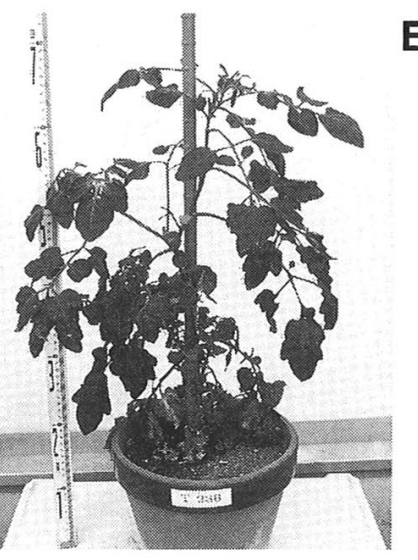

B

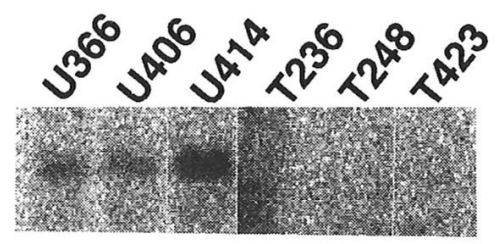

Fig. 5 Levels of Wiv-1 mRNA in leaves of the transformants.

Each lane was loaded with $3 \mu \mathrm{g}$ of total RNA from source leaves. The RNA was fractionated on an agarose gel under denaturing conditions with glyoxal-dimethyl sulfoxide and then blotted onto a membrane. The blot was probed with ${ }^{32} \mathrm{P}$-labeled Wiv-2 cDNA.

in source leaves of the 3 transformants were less than those in the control plants (Fig. 5).

\subsection{Carbohydrate content of source leaves}

The contents of soluble sugars and starch in leaves of the 3 transformants were lower than in the control plants (Table 2). The average contents of the various carbohydrates in the transformants were reduced to about $20 \%$ to $60 \%$ of those of the control plants (calculated from the data in Table 2). The sucrose content of the transformants was markedly decreased (Table 2; about $20 \%$ of that in the control plants on average).

\section{Discussion}

\subsection{Antisense suppression of cell-wall-bound acid invertase in leaves and analysis of carbohydrates}

We introduced an antisense gene for wound-inducible, cell-wall-bound acid invertase (Fig. 1; pBWI-2) into cultivated tomato. Enzyme activities in wounded source leaves of transformants T236, T248, and T423 were markedly less than those of the control plants (Fig. 4). The level of Wiv-1 mRNA in those transformants was less than in control plants (Fig. 5). These results suggest that the antisense modification 
Table 1 Fertility of tomato plants transformed with an antisense Wiv-2 gene (pBWI-2).

\begin{tabular}{|c|c|c|c|}
\hline \multirow{2}{*}{ Plants } & \multicolumn{2}{|c|}{$\begin{array}{l}\text { Percentage of stained } \\
\text { pollen grains }\end{array}$} & \multirow{2}{*}{$\begin{array}{l}\text { Relative value } \\
\text { of fruit number }\end{array}$} \\
\hline & Exp. 1 & Exp. 2 & \\
\hline $\begin{array}{l}\text { U366* } \\
\text { (control) }\end{array}$ & 81.7 & 84.1 & +++ \\
\hline $\begin{array}{l}\text { U404* } \\
\text { (control) }\end{array}$ & 87.3 & 82.6 & +++ \\
\hline $\begin{array}{l}\text { U406* } \\
\text { (control) }\end{array}$ & 67.6 & 69.3 & +++ \\
\hline $\begin{array}{l}\text { U414* } \\
\text { (control) }\end{array}$ & 86.0 & N.D. & +++ \\
\hline $\mathrm{T} 147$ & 34.4 & 6.58 & - \\
\hline T205 & 27.9 & 8.47 & \pm \\
\hline T208 & 56.5 & 6.56 & - \\
\hline $\mathrm{T} 213$ & 79.4 & 83.1 & \pm \\
\hline $\mathrm{T} 236$ & 69.4 & 40.5 & - \\
\hline $\mathrm{T} 248^{* *}$ & 40.1 & N.D. & \pm \\
\hline $\mathrm{T} 267$ & 76.8 & N.D. & ++ \\
\hline T365 & 20.9 & 13.5 & + \\
\hline $\mathrm{T} 423$ & 1.10 & 0.00 & - \\
\hline
\end{tabular}

${ }^{*}$ nontransformant ${ }^{* *}$ stunted N.D.: not determined

reduces the mRNA level and the enzyme activity in leaves of the transformants. It seems unlikely that the expression of soluble acid invertase is also suppressed by the antisense gene (pBWI-2) since the antisense $A i v-1$ gene for soluble acid invertase had no effect on the activity of cell-wall-bound enzyme in tomato leaves (Ohyama et al., 1995). Although 1 transformant, T248, was stunted, growth of the other 8 transformants (including T423, which showed the lowest activity of cell-wall-bound enzyme among the transformants) was normal (Fig. 3). We consider that the inhibition of growth observed in T248 could have been caused by somaclonal variation, not by the antisense inhibition of the enzyme synthesis.

Contents of carbohydrates in source leaves of 3 transformants (T236, T248, T423) were less than those in the control plants (Table 2). It has been reported that overexpression of yeast invertase in the apoplast leads to an increase in carbohydrates in leaves of tobacco (Sonnewald et al., 1991) and tomato (Dickinson et al., 1991) plants. The increased activity in transformants is thought to degrade sucrose in the apoplast, inhibit phloem unloading, and thus increase sugar levels in the leaves (Dickinson et al., 1991, Sonnewald et al., 1991). The reduced levels of carbohydrates observed in this study (Table 2) may support the above hypothesis from the reverse direction.

\subsection{Relationships between fertility and cell-wall- bound acid invertase}

Most of the transformants containing the antisense gene showed low fertility, whereas the untransformed controls showed normal fertility (Table 1). It is possible that the low fertility is due to the effect of the antisense gene, not to somaclonal variation. Cellwall-bound acid invertase may participate in sink strength (Weber et al., 1995, 1996, Cheng et al., 1996) and phloem unloading (Ruan and Patrick 1995, Ho 1996, Brown et al., 1997). Therefore, the decrease in the number of fruit and stained pollen grains in the transformants (Table 1) suggests that the cell-wallbound invertase encoded by Wiv-1 participates in sink metabolism in flower tissues of tomato. The presence of high levels of Lin6 (Wiv-1) mRNA in small flower buds of tomato (Godt and Roitsch 1997) may support this hypothesis. Furthermore, the growth of petunia pollen tubes is reported to be accompanied by hexose transport (Ylstra et al., 1998).

\section{References}

Brown, M. M., Hall, J. L., Ho, L. C., 1997. Sugar uptake by protoplasts isolated from tomato fruit tissues during various stages of fruit growth. Physiol. Plant., 101: 533-539.

Cheng, W.-H., Taliercio, E. W., Chourey, P. S., 1996. The miniature 1 seed locus of maize encodes a cell wall invertase required for normal development of endosperm and maternal cells in the pedicel. Plant Cell, 8: 971-983.

Table 2 Carbohydrate contents in mature leaves of tomato transformed with an antisense Wiv-2 gene (pBWI-2).

\begin{tabular}{|c|c|c|c|c|c|c|}
\hline \multirow[b]{2}{*}{ Plants } & \multicolumn{6}{|c|}{ Carbohydrate content ( $\left.\mathrm{mg}(\mathrm{g} \text { fresh weight })^{-1}\right)$} \\
\hline & $\begin{array}{l}\text { Sucrose } \\
\text { (A) }\end{array}$ & $\begin{array}{l}\text { Glucose } \\
\text { (B) }\end{array}$ & $\begin{array}{l}\text { Fructose } \\
\text { (C) }\end{array}$ & $\begin{array}{c}\text { Total soluble } \\
\text { sugars } \\
(\mathrm{A}+\mathrm{B}+\mathrm{C})\end{array}$ & $\begin{array}{l}\text { Starch } \\
\text { (D) }\end{array}$ & $\begin{array}{c}\text { Total carbo- } \\
\text { hydrate } \\
(\mathrm{A}+\mathrm{B}+\mathrm{C}+\mathrm{D})\end{array}$ \\
\hline U366* (control) & $1.47 \pm 0.13$ & $1.05 \pm 0.15$ & $3.70 \pm 0.21$ & $6.22 \pm 0.42$ & $23.7 \pm 4.57$ & $29.9 \pm 4.48$ \\
\hline U404* (control) & $0.45 \pm 0.21$ & $0.54 \pm 0.17$ & $2.72 \pm 0.34$ & $3.70 \pm 0.71$ & $7.70 \pm 1.68$ & $11.4 \pm 1.15$ \\
\hline U406* (control) & $0.35 \pm 0.25$ & $0.53 \pm 0.19$ & $2.00 \pm 0.40$ & $2.88 \pm 0.84$ & $16.6 \pm 0.78$ & $19.5 \pm 1.04$ \\
\hline U414* (control) & $1.00 \pm 0.19$ & $1.04 \pm 0.28$ & $2.88 \pm 0.56$ & $4.93 \pm 0.99$ & $9.87 \pm 1.53$ & $14.8 \pm 0.55$ \\
\hline $\mathrm{T} 236$ & $0.13 \pm 0.06$ & $0.15 \pm 0.03$ & $1.40 \pm 0.10$ & $1.68 \pm 0.17$ & $2.54 \pm 0.42$ & $4.22 \pm 0.27$ \\
\hline $\mathrm{T} 248$ & $0.20 \pm 0.08$ & $0.32 \pm 0.05$ & $1.70 \pm 0.17$ & $2.22 \pm 0.30$ & $3.35 \pm 0.51$ & $5.57 \pm 0.49$ \\
\hline $\mathrm{T} 423$ & $0.18 \pm 0.13$ & $0.22 \pm 0.11$ & $1.90 \pm 0.34$ & $2.30 \pm 0.56$ & $9.83 \pm 3.73$ & $12.1 \pm 3.80$ \\
\hline
\end{tabular}


Dickinson, C. D., Altabella, T., Chrispeels, M. J., 1991. Slow-growth phenotype of transgenic tomato expressing apoplastic invertase. Plant Physiol., 95: 420-425.

Godt, D. E., Roitsch, T., 1997. Regulation and tissuespecific distribution of mRNAs for three extracellular invertase isoenzymes of tomato suggests an important function in establishing and maintaining sink metabolism. Plant Physiol., 115: 273-282.

Hisajima, S., Arai, Y., 1978. Cell wall-bound invertase of morning-glory callus. J. Jap. Soc. Starch Sci., 25: 163-170.

Ho, L. C. 1996. Tomato. In: Zamski, E., Schaffer, A. A. (Eds.): Photoassimilate Distribution in Plants and Crops, 709-728. Marcel Dekker, Inc., New York.

Karuppiah, N., Vadlamudi, B., Kaufman, P. B., 1989. Purification and characterization of soluble (cytosolic) and bound (cell wall) isoforms of invertases in barley (Hordeum vulgare) elongating stem tissue. Plant Physiol., 91: 993-998.

Krishnan, H. B., Blanchette, J. T., Okita, T. W., 1985. Wheat invertases. Characterization of cell wall -bound and soluble forms. Plant Physiol., 78: 241-245.

Murray, M. G., Thompson, W. F., 1980. Rapid isolation of high molecular weight plant DNA. Nucleic Acids Res., 8: 4321-4325.

Ohyama, A., Ito, H., Sato, T., Nishimura, S., Imai, T., Hirai, M., 1995. Suppression of acid invertase activity by antisense RNA modifies the sugar composition of tomato fruit. Plant Cell Physiol.,
36: $369-376$.

Ohyama, A., Nishimura, S., Hirai, M., 1998. Cloning of cDNA for a cell wall-bound acid invertase from tomato (Lycopersicon esculentum) and expression of soluble and cell wall-bound invertases in plants and wounded leaves of $L$. esculentum and L. peruvianum. Genes Genet. Syst., 73: 149-157.

Ruan, Y.-L., Patrick, J. W., 1995. The cellular pathway of postphloem sugar transport in developing tomato fruit. Planta, 196: 434-444.

Sonnewald, U., Brauer, M., von Schaewen, A., Stitt, M., Willmitzer, L., 1991. Transgenic tobacco plants expressing yeast-derived invertase in either the cytosol, vacuole or apoplast: a powerful tool for studying sucrose metabolism and sink/source interactions. Plant J., 1: 95106.

Weber, H., Borisjuk, L., Heim, U., Buchner, P., Wobus, U., 1995. Seed coat-associated invertases of fava bean control both unloading and storage functions: cloning of cDNAs and cell type-specific expression. Plant Cell, 7: 18351846.

Weber, H., Borisjuk, L., Wobus, U., 1996. Controlling seed development and seed size in Vicia faba: a role for seed coat-associated invertases and carbohydrate state. Plant J., 10: 823-834.

Ylstra, B., Garrido, D., Busscher, J., van Tunen, A. J., 1998. Hexose transport in growing petunia pollen tubes and characterization of a pollenspecific, putative monosaccharide transporter. Plant Physiol., 118: 297-304. 